Marleen de Bueger ${ }^{\circ}$, Frank Verreck ${ }^{\circ}$, Els Blokland ${ }^{\circ}$, Jan Wouter Drijthout ${ }^{\circ}$, Reinout Amons ${ }^{\square}$, Frits Koning ${ }^{\circ}$ and Els Goulmy ${ }^{\bigcirc}$

Department of Immunohaematology and Bloodbank, University Hospital Leiden ${ }^{\circ}$ and Department of Medical Biochemistry, Silvius Laboratories ${ }^{\square}$, Leiden

\section{Isolation of an HLA-A2.1 extracted human minor histocompatibility peptide*}

\begin{abstract}
Purified HLA-A2.1 molecules obtained by atfintty chromatography of $6 \times 10^{16}$ Epstein Barr virus (EBV)-transformed B lymphocytes were used in an attempt 10 isolate the human HLA-A2.1-restricted minor histocompatibility $(\mathrm{H})$ peptides H-Y and HA-2. Fraction 18 of the high-performance liquid chromatograph (HPLC)-separated HLA-A2.1 peptide pool was found to contan the ndturdl HA-2 peptide. An HA-2-specific, HLA-A2.1-restricted cytotoxic T lymphocite clone lysed HLA-A2.1+ HA-2- EBV-transformed B lymphocyte cell lines reproducibly and in a concentration-dependent fashon in the presence of traction 18 , but not in the presence of other HPLC fractions. By contrast. H-Y sensitizing activity was not found in any fraction. Amino acid sequencing of peptide traction 18 revealed a mixture of peptides with maximal length of nine amıno acids. In which the presence of Leu at positions 2 and 9 was dommant. Surprisingly. the HA-2 peptide could not be mimicked by any of the peptide mixtures synthesized according to the amino acid sequences found in fraction 18. Our falure to obtam the actual amino acid sequence of the human minor $\mathrm{H}$ peptıde HA-2 from a peptide pool with the established pattern for binding to HLA-A2.1 may indicatc that this CTL defined minor $H$ peptide does not represent an abundant HLA-A2.1 binding peptide.
\end{abstract}

\section{Introduction}

Minor histocompatibility $(\mathrm{H})$ antigens represent serious barriers for succesful organ and bone marrow transplantation (BMT) between individuals matched for the major histocompatibility complex (MHC) antigens. Minor $\mathrm{H}$ antigens in general fail to induce $\mathrm{B}$ cell responses and are characterized by $\mathrm{MHC}$-restricted $\mathrm{T}$ cell responses $[1,2]$. Due to the lack of available antibodies, thus far little is known concerning the genes encoding human minor $\mathrm{H}$ antigens and their polymorphic gene products [3]. Recent$\mathrm{ly}$, it has become evident that, like virus-specific cytotoxic T lymphocytes (CTL) $[4,5]$, MHC class I-restricted CTL specific for minor $\mathrm{H}$ antigens recognize short protein stretches presented by the restricting MHC class I molecule [6-8]. Another line of investigation revealed that MHC class I molecules bind and present an allele-specific set of self peptides, presumably derived from cellular proteins [9-11]. We set out to isolate CTL-defined human minor $\mathrm{H}$ peptides from the pool of peptides naturally presented by HLA-A2.1. In this report we attempted to characterize two

[I 10773]

\footnotetext{
* This work was supported by the Dutch Health Insurance Association, the J. A. Cohen Institute for radiopathology and radiation protection (IRS) and the Netherlands Kidney Foundation.
}

Correspondence: Els Goulmy. Department of Immunohaematology. University Hospital Leiden, Rijnsburgerweg 10, NL-2333 A A Leiden. The Netherlands

Abbreviations: BLCL: B lymphocyte cell line BMT: Bone
marrow transplantation

Key words: Human class I/ Mınor histocompatibility antigen
HLA-A2.1-restricted human minor $\mathrm{H}$ peptides, the malespecific antigen $\mathrm{H}-\mathrm{Y}[12]$ and a hematopoietic tissuespecific antigen termed HA-2 [2, 13].

\section{Materials and methods}

\subsection{CTL and B cell cultures}

EBV-transformed B cell lines (EBV-BLCL) were expanded in RPMI 1640 supplemented with $10 \%$ FCS and antibiotics in 11 roller-bottle flasks. CTL clone $1 \mathrm{R} 35$ specific for the male minor $\mathrm{H}$ antigen $\mathrm{H}-\mathrm{Y}$ in the context of $\mathrm{HLA}-\mathrm{A} 2.1$ was obtained from $\mathrm{PBMC}$ of a female immunized against $\mathrm{H}-\mathrm{Y}$ as a result of multiple transfusions and unsuccesful grafting of HLA-identical male bone marrow [12]. CTL clone 5H17 specific for the HLA-A2.1-restricted minor HA-2 was obtained from PBMC of a patient shortly after HLAidentical bone marrow transplantation [2]. Both minor $\mathrm{H}$-specific CTL lines were established by repeated in vitro restimulation with the original stimulator PBMC. After limiting dilution, clones were maintained by weekly stimulation with allogeneic feeder cells in RPMI 1640 supplemented with $15 \%$ pooled human serum and $20 \mathrm{U} / \mathrm{ml}$ rIL- 2 . Immunogenetic data and tissue expression of the HA-2 minor $\mathbf{H}$ antigen were previously described $[3,13]$.

\subsection{Purification of HLA-A2.1 and isolation of HLA-A2.1 bound peptides}

Pellets of $6 \times 10^{10}$ EBV-BLCL were incubated for $45 \mathrm{~min}$ at $4{ }^{\circ} \mathrm{C}$ at $2 \times 10^{8}$ cells $/ \mathrm{ml}$ in a lysis buffer containing $50 \mathrm{mM}$ Tris, $150 \mathrm{~mm} \mathrm{NaCl}, 0.5 \%$ Nonidet P-40, 5 mM EDTA, pH 8 and $0.1 \mathrm{mM}$ PMSF and $1 \mu \mathrm{g} / \mathrm{ml}$ of the protease inhibitors antipain, leupeptin, chymostatin and pepstatin. Centrifugation for $5 \mathrm{~min}$ at $500 \times \mathrm{g}$ followed by $60 \mathrm{~min}$ at $10000 \times \mathrm{g}$ 
yielded a supernatant which was used to purify HLA-A2 1 by affinity chromatography The antibodies 75101 (ant1HLA class II) and BB7 2 (antı-HLA-A2 1. [14]) were coupled at $5 \mathrm{mg} / \mathrm{ml}$ to $\mathrm{CNBr}$-activated Sepharose $4 \mathrm{~B}$ beads (Pharmacia LKB) The supernatant was sequentrally passed, at a flow rate of $8 \mathrm{ml} / \mathrm{h}$, through columns filled with Tris- $\mathrm{HCl}$ equilıbrated beads $(10 \mathrm{ml})$, ant $\mathrm{H}-\mathrm{HLA}$ class $I I$ beads $(2 \mathrm{ml})$ and two columns with ant1-HLA-A2 1 beads ( 7 and $4 \mathrm{ml}$ ) Beads were removed from ant $-\mathrm{HLA}-\mathrm{A} 21$ columns and incubated for $15 \mathrm{~min}$ at $+{ }^{\circ} \mathrm{C}$ in $15 \mathrm{ml} 01 \%$ trifluoroacetic acid (TFA) Supernatants were separated by centrifugation over Centricon 10 (Amicon) filters into a $>10 \mathrm{kDa}$ and $\mathrm{a}<10 \mathrm{kDd}$ fraction. The amount of puritied HLA-A2 was determined with the BCA protein dssay (Pierce) in the $>10 \mathrm{kDd}$ fraction Purification grade was
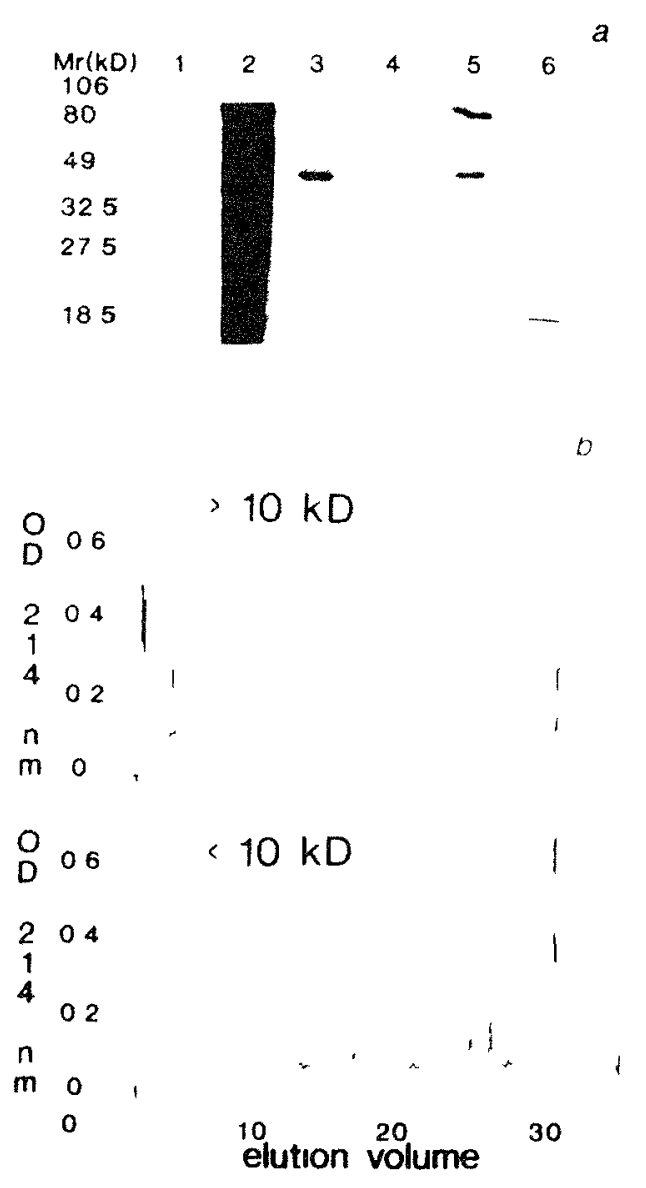

Figule! Aftinitv-purified HLA-A2 1 molecules (a) and HPLC profiles of HLA-A2 1 and ot peptides eluted from these molecules (b) (a) SDS-polvacrylamide gel $(15 \%)$ run under reducing conditrons Lane 1 standird markers with indicated molecular weight (BroRad) lane 2 unseparated lvalte lane 3 . aftinitv-purified HLA-A2 $\mathrm{I}>10 \mathrm{hDa}(+5 \mu \mathrm{g})$ lane $+<10 \mathrm{kDa}$ material eluted trom $+5 \mu \mathrm{g}$ HL $A-A 2$ 1. lane 5 HPLC fraction $2+$ of HLA-A2 1 , lane 6 HPI ( Iraction ly of HLA-A2 (b) Reterse-phase HPLC separation of high $(>10 \mathrm{kDal})$ and low $(<10 \mathrm{kDa})$ molecular mass tractoms of "lfintt-purticed HI A A? the lotd wolume pedk representing salt injectuon and the tinal peak representing NP40 were tound in all IfPL C rum Vote that the peak at 19 and $2+\mathrm{ml}$ in the $>10 \mathrm{kD}$. $11 \mathrm{~A} A-\mathrm{A} 2 \mathrm{I}$ profile represent $13 \mathrm{~m}$ and $\mathrm{H}$ chan contammated with someti2m respectuch (a lanes 6 and b top profile) monitored by silier-staned SDS-PAGE The low and high molecular weight tractions of HLA-A 1 were dried by lacuum centritugation and separated by reverse-phase HPLC using a LiChrospher (o) RP-Select B. $5 \mu \mathrm{m}$. $250 \times+\mathrm{mm}$ column (E Merch. Darmstadt. FRG) Elution butters were $\mathrm{A}$. $\mathrm{H}_{2} \mathrm{O}, \mathrm{B}$. dectonitrile: and C. 2\% TFA in $\mathrm{H}_{2} \mathrm{O}$ Gradients routinely used for separations $0-30 \mathrm{~min}$ linear increase trom $5 \%$ to $75 \%$ B or $0-45$ min linedr increase from $20 \%$ to $50 \%$ B. with $5 \%$ butter $C$ hesng used throughout all gradients. flow rate $10 \mathrm{ml} / \mathrm{mm}$ Elution $\mathrm{u}$ ds monitored bi a continuous flow spectrophotometer at $21+\mathrm{nm}$ Fractions of 1 or $05 \mathrm{ml}$ were collected and dricd hi bacuum centritugation

\subsection{Pepride sequencing and synthesis}

Low molecular werght material eluted trom HLA-A2 1 and sepdrated by HPLC was sequenced by automated Edman degradation using a pulsed-liquid protein sequencer $477 \mathrm{~A}$ equipped with an on-line PTH-amino acid analyzer 120A (Applied Biosystems) Mixtures of synthetic peptides were generated during mixed syntheses using an AMS +22 synthesizer (Abimed Analysen-Technik. FRG) and were puritied by reverse-phase HPLC Four mixtures each contaned 64 nonapeptides $X_{11} L X_{1} X_{2} X_{3} X_{4} E T L . X_{10} L X_{1} X_{2}$ $X_{7} X_{4}$ LTL. $X_{11} L X_{1} X_{2} X_{3} X_{4} A T L$ and $X_{11} L X_{1} X_{2} X_{3} X_{4} I T L$. respectively, wherein position $X_{11}$ is $A . X_{1}$ can carry either $F$ A. I or $E, X_{2}$ is D, G. E or $P, X_{3}$ is $F$ or $L$ and $X_{4}$ is I or $L$ Four additional mixtures. edch contaming 1280 peptides also had all 20 natural amino dcids on $X_{11}$

\section{$2.4{ }^{51} \mathrm{Cr}$-release assay}

${ }^{51} \mathrm{Cr}$-labeled EBV-transformed B lymphocytes $\left(2.5 \times 10^{3}\right)$ were preincubated in $50 \mu \mathrm{l}$ with either naturally eluted or synthetic peptides for $30 \mathrm{~min}$ at $37^{\circ} \mathrm{C}$. HPLC-purified synthetic peptides were tested in final concentrations between 0 16-50 nM. Dried HPLC fractions of the HLAA2.1-eluted peptides were resuspended in PBS $+50 \mathrm{~mm}$ He pes (usually $250 \mu \mathrm{l}$ ) of which $25 \mu \mathrm{l}$ (or serial dilutions) were added to the wells. Subsequently $100 \mu \mathrm{l} 15 \%$ human serum in RPMI with or without (spontaneous release values) $10^{5}$ effector cells was added to each well and incubated for $4 \mathrm{~h}$ at $37^{\circ} \mathrm{C}$. Radioactivity released into the supernatant was determined in a Packard $\gamma$-counter. Spontaneous release values for EBV-BLCL were 19-32\%

\section{Results}

HLA-A2.1 was purified by affinity chromatography [9] from an HLA-A2.1 EBV-BLCL expressing both H-Y and HA-2 minor $\mathrm{H}$ antigens. In total $3.3 \mathrm{mg}$ protein was eluted from the ant1-HLA-A2.1 mAb-coated columns. SDSPAGE and reverse-phase HPLC revealed that this material mainly represented $\beta 2$-microglobulin $(\beta 2 \mathrm{~m})$ and $H$ chain (Fig 1a, b). Quantification of the HPLC $\beta 2 \mathrm{~m}$ peak, by comparison with peak sizes of known amounts purified $\beta 2 \mathrm{~m}$, indicated that $127 \mu \mathrm{g}$ or $2.35 \mathrm{nmol}$ HLA-A2.1 was recovered atter HPLC. Naturally bound peptides copurified with HLA-A2.1 were separated from $\beta 2 \mathrm{~m}$ and $\mathrm{H}$ chain by acid treatment followed by ultrafiltration (cutoff 


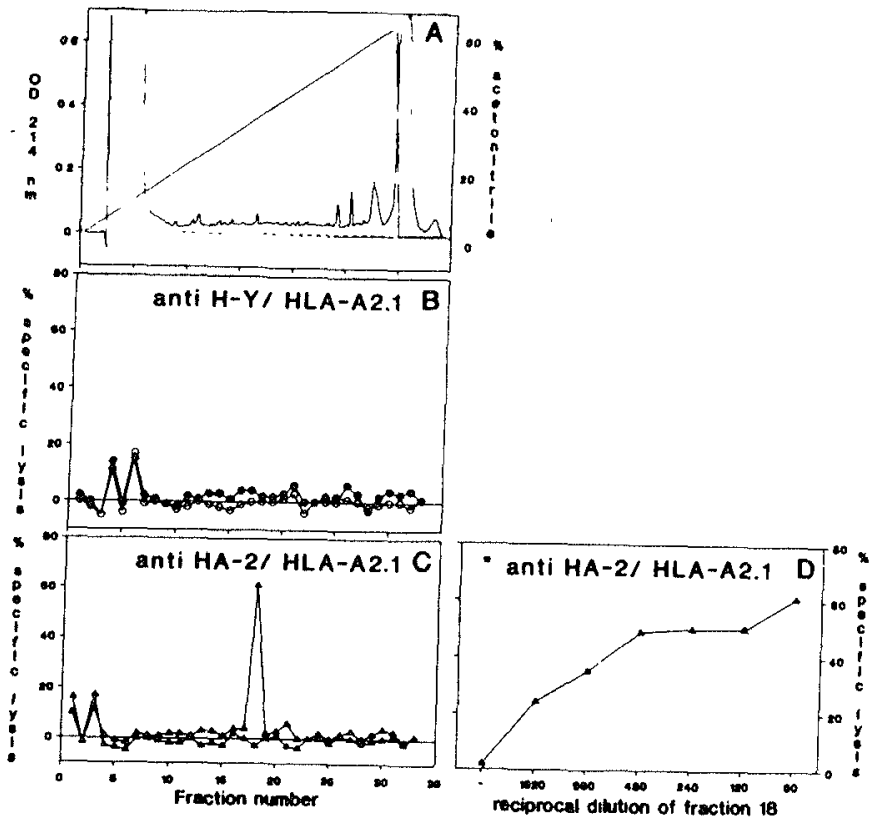

Figure 2. HLA-A2.1 peptide fraction 18 contans minor HA-2. The peptide content from $2.35 \mathrm{nmol}$ HLA-A2.1 affinity-purified from EBV-BLCL of a male. HLA-A2. minor HA-2-expressing individual was separated by reverse-phase HPLC (A). Individual $1-\mathrm{ml}$ fractions were tested for containing minor peptides $\mathrm{H}-\mathrm{Y}$ and HA-2 by incubating 1/60 of each fraction with HLA-A2. $1^{+}$, HA-2 ${ }^{-}, \mathrm{H}-\mathrm{Y}^{-}$BLCL in the absence (open symbols) or presence (closed symbols) of the HLA-A2-restricted anti-HY CTL clone $1 \mathrm{R} 35$ (B) or anti-HA-2 CTL clone. $5 \mathrm{H} 17$ (C) at $E / T=40$. Positive fraction 18 was retested in titrated amounts $(1 / 60-1 / 1920$ of fraction 18; total peptide pool content: $2.35 \mathrm{nmol}$ ) for recognition by HLA-A2-restricted anti-HA-2 CTL (D) and was compared to the original HLA-A2 ${ }^{+}, \mathrm{HA}-2^{+}$donor BLCL without added peptide (D, $\mathbf{v})$.

$10 \mathrm{kDa})$. Low molecular mass molecules $(<10 \mathrm{kDa})$ ivere fractionated by reverse-phase HPLC (Fig. 2A). Individual fractions were then tested for recognition by HLA-A2.1restricted CTL specific for H-Y (Fig. 2B) and for HA-2 (Fig. 2C). None of the fractions rendered HLA-A2.1 female EBV-BLCL susceptible to lysis by anti-H-Y CTL (Fig. 2B). In contrast. HLA-A2.1+ . HA-2- BLCL incubated with fraction 18 were effectively lysed by anti-HA-2 CTL (Fig. 2C), whereas none of the other fractions could sensitize the target cells for HA-2. Fraction 18 could be diluted more than $20(0)$-fold and still sensitize target cells for HA-2 recognition (Fig. 2D). Comparable HA-2-sensitizing activity was found in HPLC fraction 18 of unseparated HLA-A2.1, but not in the high molecular mass (> $10 \mathrm{kDA}$ ) material of filtered HLA-A2.1 (not shown). HA-2 reproducibly eluted in one fraction at a constant position in the HPLC spectrum. Repeated isolation of the peptide content of HLA-A2.1 molecules derived from $4 \times 10^{10} \mathrm{EBV}-\mathrm{BLCL}$ yielded identical results (data not shown).

The HA-2-containing fraction 18 was sequenced by Edman degradation and found to contain more than one peptide (Table 1). None of the peptides was more than nine amino acids in length. A dominant Leu was found at positions 2 and 9. To obtain a purer fraction. containing only the $\mathrm{HA}-2$ peptide, a second HLA-A2.l peptide pool was separated

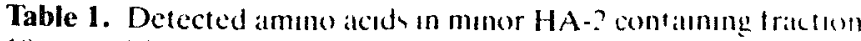
Is at positions $1-9$ it

$\begin{array}{lcccccccc}1 & 2 & 3 & 4 & 5 & 6 & 7 & 8 & 9 \\ \text {-b) } & \text { L } & \text { F }) & \text { D } & \text { F } & \text { I } & \text { E } & \text { T } & \text { L } \\ & & \text { A } & \text { G } & \text { L } & \text { L } & \text { L } & & \\ & & \text { I } & \text { E } & & & \text { A } & & \\ & & \text { E } & \text { P } & & & \text { I } & & \end{array}$

a) HPLC peptide fraction 18 obtaned from $1.77 \mathrm{nmol}$ purticed HLA-A2 was sequenced by Edman degradation. D-termmal peptide yield was 107 pmol decreasing to $20 \mathrm{pmol}$ at the C-terminal position 9. Detection limit was 5 pmol . Vo yenti. cant levels were detected bevond position 9.

b) Significant amounts of all 20 ameno aceds were found at pust tion 1.

c) Significant amounts of the amino acids indicated were found.

by HPLC using a shallower gradient $(20-50 \%$ in $45 \mathrm{~min}$ with $0.5 \mathrm{ml}$ fractions instead of $5-75 \%$ in $30 \mathrm{~min}$ with $1 \mathrm{ml}$ fractions). Subsequent cell-mediated lysis analysis indcated two fractions with HA-2 activity. However, sequence analysis of the pooled fractions revealed again a nonapeptide mixture with virtually identical amino acids as found in fraction 18 (see Table 1).

To identify which of the eluted nonapeptides represented the naturally processed HA-2 minor peptide, eight mixtures of nonapeptides covering all peptides possibly present in fraction 18 (see Sect. 2.3) were synthesized, fractionated by HPLC and tested for their ability to induce lysis by anti-HA-2 CTL. However, none of the peptide mixtures could sensitize HA-2- BLCL for recognition by anti-HA-2 CTL at concentrations as high as $500 \mathrm{pM}$ (data not shown).

\section{Discussion}

Minor $H$ antigen HA-2 was initially defined by HLAA2.1-restricted CTL isolated from PBL after MHC-identical, HA-2-mismatched BMT [2]. The HA-2 ${ }^{+}$phenotype has a frequency of $95 \%$ in the HLA-A2.1 ${ }^{+}$population [3]. In contrast to the previously isolated murine minor $H$ peptides $\mathrm{H}-\mathrm{Y}$ and $\mathrm{H}-4^{b}$ which are ubiquitously expressed, HA-2 is expressed only by cells of hematopoietic origin [13]. In the situation of MHC-matched, HA-2-mismatched BMT, therefore, these anti HA-2 CTL are not likely to inflict graft-versus-host (GVH) reactions (GVH-target tissues, e.g. the skin, does not express HA-2), but might be involved in the so-called graft-versus-leukemia effect [15]. Here, the natural HA-2 peptide presented by HLA-A2. 1 to CTL is shown to be present within an HLA-A2.1 peptide fraction containing predominantly nonapeptides with Leu as dominant amino acid at positions 2 and 9 . Thus, this findıng is compatible with two previous reports indicating that naturally processed HLA-A2.1-bound self peptides are mainly nonapeptides and carry Leu at position 2 and either Leu or Val at the carboxy-terminal position $9[9,10]$. 
Unexpectedly, however, none of the synthetic peptide mixtures, covering all nonameric sequences indicated by the observed HLA-A2 1 binding motif (Table 1), cou'd sensitize HA-2- BLCL for recognition by ant1-HA-2 CTL The fallure to detect the HA-2 peptide in the peptide mixtures based on the observed A2 1 motif might be due to (1) competition for binding to HLA-A2 1 between the peptides present in each tested mixture, or (2) absence of the HA-2 amino acid sequence among the series of synthetic peptides tested At this stage we cannot rule out the first possibility Additional separate testing will be required to exclude the possibility of competition The second explanation would indicate that the amount of HA-2 peptide present in fraction 18 was insufficient to be detected Should fraction $18(100 \mathrm{pmol}$ total peptide content based on Edman degradation) contain 20 or more different peptides in equimolar amounts, 1 of which being HA-2, then HA-2 would already be below the detection limit of the PTH amino acid analyzer used (5 pmol) Given the recent estimate that the HLA-A2 1 molecules of a given cell might contain 200 to 1000 distinct nonapeptides [10], this explanation is not unlikely These results stress the enormous sensitivity of a CTL in detecting peptide in the context of an MHC class I molecule Ant1-HA-2 CTL could detect as hittle as 1 in 1920 of the material of fraction 18 which apparently contained insufficient of the HA-2 peptide to be measured by Edman degradation Our observations are in line with previous reports on the isolation of minor $\mathrm{H}$ peptides from lysates of whole cells The murine $\mathrm{H}-2^{\mathrm{b}}$-restricted minor $\mathrm{H}$ antigens $\mathrm{H}-\mathrm{Y}, \mathrm{H}-4^{\mathrm{b}}$ and Mapk 1 and an HLA-B35-restricted antigen were detectable by the appropriate CTL, but could not be identified as single peptides [5-7] Recent sequence analysis of the self-peptide pool present in HLA-A2 1 and HLA-B27 revealed the presence of a limited number of "dominant" peptides which were present in sufficient amounts to allow sequence analysis $[10,11]$ Our inability to elucidate the amino acid sequence within the peptide pool derived from $235 \mathrm{nmol}$ HLA-A2 1 may indicate that this minor $\mathrm{H}$ peptide is not present in comparable amounts to those "dominant" self peptides of which sufficient copies are avallable to allow identıfication as single peptıdes and which determine the peptide-binding profile In fact, it can not be excluded at this point that self peptides, present in quantities undetectable with the current biochemical methods, may not follow the MHC class I allele-specific binding rules based on the composition of the abundant peptides The fact that HLA-A2 1-restricted CTL epitopes exist, defined by synthetic peptides which do not fit the HLA-A2 1 binding protile determined thus far, would be compatible with this hypothesis [16. 17] Starting with larger amounts of purified MHC class I (here $6 \times 10^{10}$ cells were used, yielding 235 nmol pure HLA-A2 1 after HPLC) may allow detection of these minor peptides and determination of MHC class I binding profiles in more detail

Our inability to detect the H-Y, in contrast to the HA-2, peptide thus tar could be due to (a) a lower number of H-Y peptides per HLA-A2 1 molecule. (b) inability of $\mathrm{H}-\mathrm{Y}$ to replace endogenously bound self peptides $i n$ vitro due to a lower attinity or (c) selective loss of H-Y during purification At this point we cannot exclude any of these possibilities Future purification of $\mathrm{H}-\mathrm{Y}$ peptides from las ger amounts of HLA-A2 1 as suggested earlier may lead to lis detection
Although the first human minor $H$ protein still awats identification. in the mouse polymorphic self proteins located in the cytosol [18] and in mitochondria [19]. as well as proteins encoded by retroviral genes [20], can represent minor $\mathrm{H}$ proteins. $t e$ induce MHC class I-restricted CTL and skin-graft rejection From this, it may be concluded that within any given cell a large source of potential mınor $\mathrm{H}$ protenns might be present Fortunately, based on the recent understanding of the MHC class I-processing pathway. it may be expected that only a small and selected fraction of the total pool of peptides derived from these protens will make it to the cell surface, and that again only a selected fraction of these cell surface peptides will manifest itself as minor $\mathrm{H}$ peptide Criterid resulting in this peptide selection will include (1) a sufficiently high affınıty for binding to one of the avallable MHC class I molecules. (2) presence of a sufficient number of copies resultung in the minimal number of MHC-peptide complexes at the cell surface required for Tcell activation [21], and (3) polymorphism of the peptide and immunogenicity of the MHCpeptide complex formed Should, in contrast to the total number of distinct class I-bound cell surface peptides (estımated 200-1000 for HLA-A2 1), the number of T cellactıvatıng minor $\mathrm{H}$ peptides per MHC class I allele be limited to a few or even one, then clinical applications in minor $\mathrm{H}$-mismatched BMT would belong to the future possibilities

The authors would like to thank $\operatorname{Dr} C$ Meltef and $D r R$ de Vries for critical reading of the manuscript

Received July 3, 1992, in revised form October 221992

\section{References}

1 Wettstein, P J, in Litwin, S (Ed), Human Immunogenetics, Dekker, New York 1989, p 339

2 Goulmy, E Transplant Rev 1988229

3 Van Els, C A C M et al, Immunogenetics 199235161

4 Van Bleek, G M and Nathenson, S G , Nature 19903348 213

5 Rotzschke, O, Falk, K, Deres, K, Schild, H , Norda, M , Metzger, J , Jung, $G$ and Rammensee, H -G , Nature 1990 348252

6 Rotzschke, O , Falk, K, Wallny, H -J , Faath, S and Rammensee, H-G, Sctence 1990249283

7 Falk, K, Rotzschke, O and Rammensee, H -G , Nature 1990 348248

8 Sekımata, M , Griem, P, Egawa, K , Rammensee, H -G and Takiguchi, M, Int Immunol 199242,301

9 Falk, K, Rotzschke, O, Stevanovic, S, Jung, G and Rammensee, H-G , Nature 1991351290

10 Hunt, D F, Henderson, R A , Shabanowitz, J, Sakaguchı, K , Michel, H, Sivilir, N, Cox, A L, Appela, E and Engelhard, V H, Sctence 19922551261

11 Jardetzky, T S, Lane, W S, Robinson, R A, Madden, D R , Wiley, D C, Nature 1991353326

12 Goulmy, E ,Termutelen, A , Bradley, B A and van Rood, J J , Nature 1977266544

13 De Bueger, M , Bakker, A , Van Rood, J J , van der Woude, F and Goulmy E, J Immunol 19921491788

14 Parham P and Brodsky, F M , Hum Immunol 19813277

15 Van Lochem, E, De Gast, B and Goulmy, E, Bone Marrow Transplant $1992 \quad 10 \quad 181$ 
16 Clavene, J -M., Kourlsky, P, Langlade-Demoyen, P, Chalufour-Prochnicka, A, Dadaglıo, G . Tekard, F. Plata F and Bougueleret, L, Eur J Immunol 1988181547

17 Penna, A, Chisan, FV, Bertolettı, A , Missale, G , Fowler P Ginbert, T, Fraccadorı, F and Ferrarı, C J Exp Med 1991 $174 \quad 1565$

18 Speiser, D E, Zurcher, T, Ramseler, H, Hengartner. H Stacheh, P, Haller, $\mathrm{O}$ and Zinkernagel R M Proc Natl Acad ScI USA $1990 \quad 872021$
19 Loveland B Wang $C R$ Yonekathd $H$ Hermel I ind Fischer Lindahl K (ell 1990 of) 971

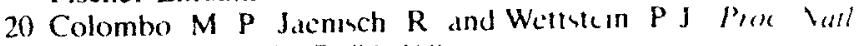
load bat USA 1987 84 139

21 Christunck $E R$ Luscher $M$ A Barher B H and Wilhim D B Nature 1991 352 67 